\title{
PELATIHAN PEMBELAJARAN JARAK JAUH (PJJ) PADA MASA PANDEMI COVID-19 BAGI GURU SEKOLAH DASAR ISLAM TERPADU (SDIT) DOD MEDAN
}

\author{
Suhendri ${ }^{*}$, Rijal Sabri*2, Zainal Arifin*3, M. Arif Rahman*4, Tharina Ainaya*5, dan Hendra \\ Alsa Fahmi*6 \\ ${ }^{123}$ Dosen Fakultas Agama Islam, ${ }^{4}$ Dosen Fakultas Teknik dan Ilmu Komputer, \\ ${ }^{56}$ Mahasiswa Fakultas Agama Islam, Universitas Dharmawangsa, Medan, Indonesia \\ *Penulis Korespodensi : ${ }^{1}$ suhendri165@dharmawangsa.ac.id, ${ }^{2}$ rijal.sabri@dharmawangsa.ac.id, \\ ${ }^{3}$ zainalarifin@dharmawangsa.ac.id, ${ }^{4}$ arif@dharmawangsa.ac.id, ${ }^{5}$ tharinainaya@gmail.com, ${ }^{6}$ hendraalsa@gmail.com
}

\begin{abstract}
Abstrak
Pembelajaran jarak jauh adalah salah satu alternatif model pembelajaran di masa pandemi Covid-19. Sebagai sesuatu yang baru, model pembelajaran jarak jauh harus disosialisasikan dan dilatihkan bagi guru-guru terutama guru di sekolah dasar. Karena itu,tim pengabdian masyarakat melakukan kegiatan pengabdian di Sekolah Dasar Islam Terpadu (SDIT) DOD Medan dengan melaksanakan pelatihan pembelajaran jarak jauh bagi guru-guru. Dalam kegiatan pengabdian masyarakat ini, guru-guru SDIT DOD Medan diberikan pemahaman untuk menerima situasi sulit ini dan mampu beradaptasi dalam melakukan pembelajaran di masa pandemic Covid-19. Selain itu, guru-guru juga dilatih dalam mendisain perencanaan pembelajaran yang ringkas serta pengelolaan pembelajaran jarak jauh baik secara luar jaringan maupun dalam jaringan, dilatih membangun Learning Management System (LMS) di sekolah, dan dilatih memaksimalkan sistem dukungan orangtua dalam mendungkung moda PJJ di sekolah selama masa pandemi Covid-DOI: https//doi.org/10.24114/jpkm.v27i1.22128 n bahwa guru-guru SDIT DOD Medan mampu ......... pembelajaran jarak jauh baik luar jaringan maupun dalam jaringan,sekolah membangun Learning Management System (LMS), dan sekolah mendapatkan dukungan orangtua dalam pembelajaran di masa pandemi Covid-19. Berdasarkan kegiatan pengabdian masyarakat ini, sebagai tindak lanjut, diharapkan kepada pemangku kebijakan dan lembaga terkait untuk ambil bagian dalam melakukan kegiatan pendampingan dan dukungan terhadap guru-guru dalam mengelola pembelajaran sekaligus melakukan monitoring dan evaluasi terhadap proses pembelajaran selama pandemi Covid-19.
\end{abstract}

Kata kunci: Peserta didik, pembelajaran jarak jauh, pandemi Covid-19

\begin{abstract}
Distance learning is an alternative learning model during the Covid-19 pandemic. As something new, the distance learning model must be socialized and trained for teachers, especially teachers in elementary schools. Therefore, the community service team carried out community service activities at the Integrated Islamic Elementary School (SDIT) DOD Medan by conducting distance learning training for teachers. In this community service activity, the teachers of SDIT DOD Medan were given the understanding to accept this difficult situation and were able to adapt to learning during the Covid-19 pandemic. Besides, teachers are also trained in designing concise lesson plans and management of distance learning both offline and online, are trained to build Learning Management Systems (LMS) in schools and are trained to maximize parental support systems in supporting PJJ modes in schools. during the Covid-19 pandemic. The results of this community service activity show that the teachers of SDIT DOD Medan can open up and want to adapt to the Covid-19 situation and can design distance learning both offline and online, schools build Learning Management Systems (LMS), and schools get support from parents in learning during the Covid-19 pandemic. Based on this community service activity, as a follow-up, it is hoped that policymakers and related institutions will take part in providing assistance and support for teachers in
\end{abstract}


managing learning as well as monitoring and evaluating the learning process during the Covid-19 pandemic.

Keywords: Students, distance learning, Covid-19 pandemic

\section{PENDAhuluaN}

Sekolah Dasar Islam Terpadu (SDIT) DOD adalah sekolah Islam terpadu dikelola Yayasan Pendidikan Islam DOD Medan. Secara kelembagaan dan kewenangan pengelolaan, SDIT DOD ini berada di bawah binaan Dinas Pendidikan Kabupaten Deli Serdang. Sekolah ini berdiri di atas lahan dengan luas $950 \mathrm{~m}^{2}$. Lokasi sekolah ini berada di Jalan Klambir V, Desa Tanjung Gusta,Kecamatan Sunggal, Kabupaten Deli Serdang, Provinsi Sumatera Utara.

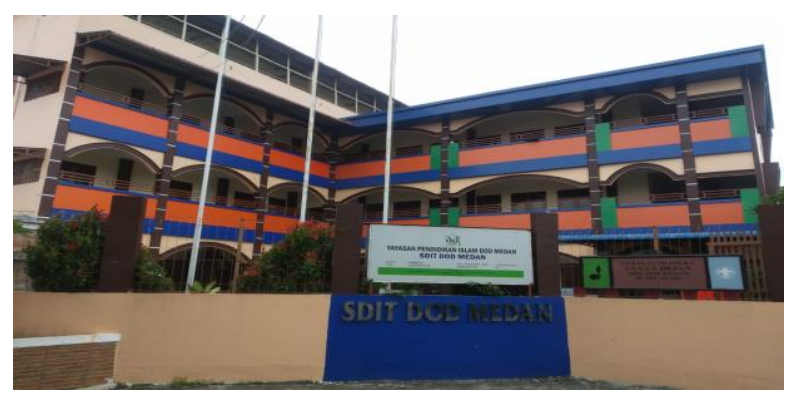

Gambar 1. Tampak Depan SDIT DOD Medan

Di masa pandemi Covid-19, pembelajaran moda tatap muka di ruang kelas pada SDIT DOD - sesuai dengan kebijakan pemerintah dan untuk atas nama menjaga keselamatan - harus dihentikan. Hal ini menyebabkan proses pembelajaran harus dilakukan dengan moda pembelajaran jarak jauh (PJJ) baik dalam jaringan (daring) maupun luar jaringan (luring). (Muhammad, 2020) di samping untuk menghindari penyebaran Covid-19 melalui kluster persekolahan (Firman \& Rahayu, 2020). Hal ini semata-mata dilakukan untuk menjamin tetap berlangsungnya proses pembelajaran bagi peserta didik dan selainnya merupakan tuntutan perubahan (Darmayanti, Tri, Setiani, Made Yudhi, Oetojo, 2007) (Isniatun, 2005).

Alih-alih untuk menjamin kualitas pembelajaran yang dilaksanakan ternyata, moda PJJ tidak mudah diterapkan guru. Hal ini disebabkan antara lain oleh kemampuan dan/atau kompetensi guru yang belum merata dalam mengelola moda PJJ (Azzahra, 2020) di samping akses internet yang belum merata (Herliandry, Luh Devi, Nurhasanah, Suban, Maria Enjelina, Kuswanto, 2020), ditambah lagi satuan pendidikan secara manajerial belum terampil dalam pengelolaan LMS. Memang disadari bahwa moda PJJ ini amat baru dalam pembelajaran Sekolah Dasar, yang secara psikis menjadi hambatan internal dalam pelaksanaan di lapangan pembelajaran.

Di samping itu, sistem dukungan moda PJJ juga belum tampak maksimal di sekolah. Sistem dukungan yang dimaksud adalah keterlibatan komunitas orangtua dalam paguyuban orangtua atau komite sekolah. Komitmen komite sekolah dalam mendukung moda PJJ amat penting dalam menjamin keberlangsungan pembelajaran yang bermutu bagi peserta didik.

Keterangan di atas menunjukkan bahwa permasalahan utama yang dihadapi SDIT DOD Medan di masa pandemi Covid-19 adalah: (a) Bagaimana mengelola pembelajaran dengan menggunakan moda PJJ, (b) Bagaimana membangun Learning Management System (LMS) di sekolah, dan (3) Bagaimana memaksimalkan sistem dukungan orangtua dalam mendungkung moda PJJ di sekolah selama masa pandemi Covid-19.

Karena itu, tim pelaksana pengabdian kepada masyarakat Universitas Dharmawangsa fokus pada tiga permasalahan tersebut dengan harapan proses pembelajaran pada masa pandemi Covid-19 bukan hanya sekadar berlangsung, tapi juga pembelajaran yang berlangsung adalah pembelajaran yang berkualitas.

\section{BAHAN DAN METODE}

Dalam pelaksanaan kegiatan pengabdian ini, Tim memanfaatkan fasilitas aula, infocus, dan soundsystem SDIT DOD Medan. Pelaksanaan kegiatan pengabdian ini dilakukan mulai tanggal 25 September s.d. 17 Oktober 2020.

Tim pelaksana memilih pelatihan sebagai metode dalam pelaksanaan kegiatan pengabdian ini. Adapun tahapan-tahapan dalam pelaksanaan pelatihan ini disesuaikan dengan solusi yang diharapkan mitra, yaitu:

a) Kebutuhan untuk meningkatan kompetensi guru dalam mengelola pembelajaran dengan moda PJJ baik daring maupun luring adalah dengan cara melaksanakan pelatihan bagi guru-guru SDIT DOD Medan dalam mengelola pembelajaran dengan moda PJJ baik melalui daring maupun luring. Pelatihan ini dilaksanakan guna meningkatkan kompetensi guru dalam mengelola pembelajaran dengan moda PJJ. Materi yang diberikan kepada guru-guru adalah pembuatan RPP Praktis dengan model RPP terbaru 
(satu halaman), pembuatan bahan ajar online/offline - dan metode evaluasi pembelajaran. Dalam pelatihan ini, guru-guru akan praktik langsung sehingga pelatihan yang dilaksanakan berhasil guna;

b) Kebutuhan untuk membangun LMS dalam mendukung pembelajaran di sekolah adalah dengan mendampingi dan/atau membantu sekolah dalam membangun LMS di sekolah. LMS akan berguna bagi sekolah dalam mendukung pembelajaran baik dengan moda tatap muka maupun PJJ. Selain itu, LMS akan memudahkan sekolah dalam memonitor kegiatan guru dan peserta didik; dan

c) Masih rendahnya sistem dukungan dari orangtua/komite sekolah untuk mendukung moda PJJ diatasi dengan mendampingi SDIT DOD Medan dalam memberikan sosialisasi tentang moda PJJ terhadap orangtua/komite sekolah sehingga diharapkan orangtua dapat melakukan pendampingan pembelajaran moda PJJ baik melalui daring maupun luring.

Untuk mensukseskan kegiatan pengabdian masyarakat yang dilakukan Universitas Dharmawangsa, SDIT DOD Medan sebagai mitra berpartisipasi aktif melalui:

a) Penyediaan lokasi/tempat di sekolah untuk mendukung pelaksanaan program pelatihan dengan tetap mengacu pada protokol kesehatan. Di samping memastikan semua guru SDIT DOD Medan terlibat secara aktif dalam kegiatan pelatihan;

b) Penyediaan akses internet bagi guru-guru selama kegiatan pelatihan berlangsung; dan

c) Mengundang beberapa perwakilan orangtua dan/atau komite sekolah untuk diberikan sosialisasi tentang moda PJJ dan bentuk dukungan orangtua dalam memberhasilkan proses pembelajaran selama masa pandemi Covid-19.

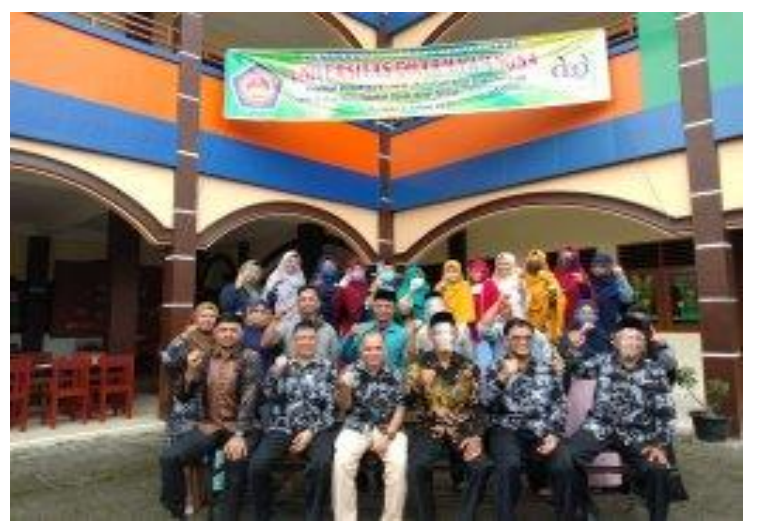

Gambar 2. Tim pelaksana pengadian dan mitra

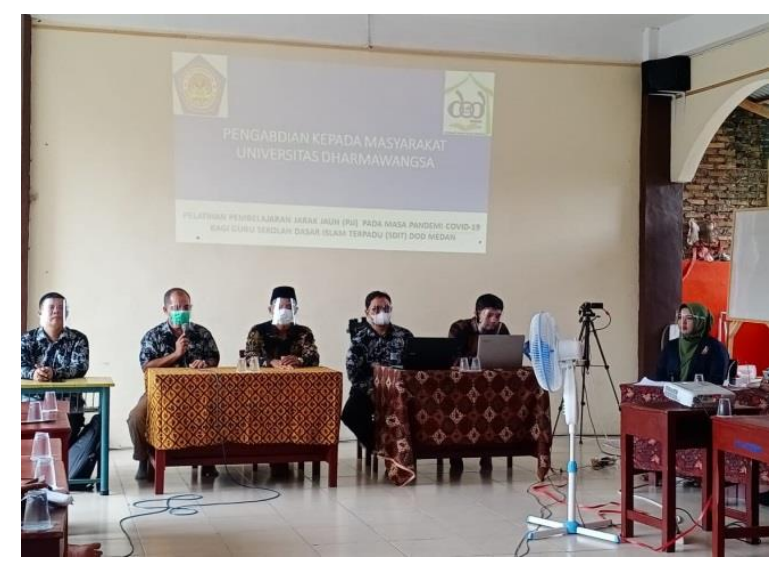

Gambar 3. Sesi pemaparan materi

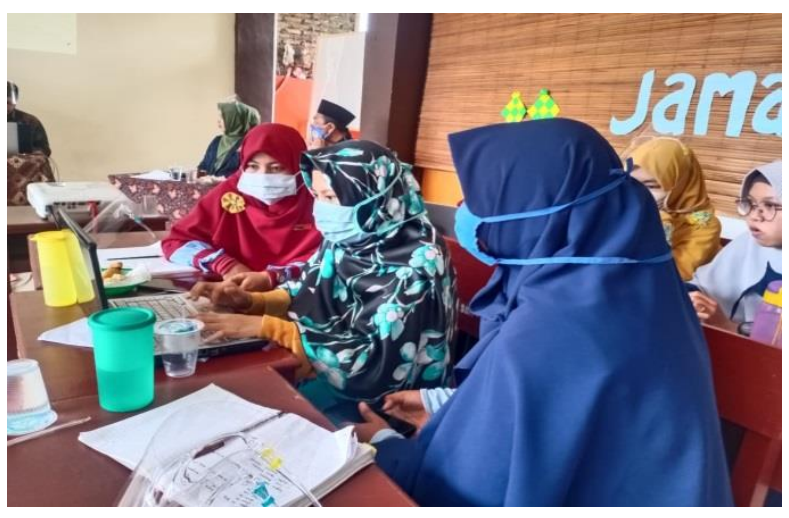

Gambar 4. Sesi diskusi dan praktik

\section{HASIL DAN PEMBAHASAN}

Tim pelaksana pengabdian Universitas Dharmawangsa melaksanakan kegiatan pengabdian pada hakikatnya merupakan bentuk dukungan Universitas Dharmawangsa dalam mendampingi mitra (SDIT DOD Medan) dalam menghadapi krisis akibat pandemi Covid-19.

Karena itu, tim pelaksana pengabdian kepada masyarakat Universitas Dharmawangsa fokus untuk mencarikan solusi terhadap permasalahan mitra (SDIT DOD Medan) dalam mengelola pembelajaran di masa pandemi Covid-19. Hasil kegiatan pengabdian kepada masyarakat dapat dilihat dalam kegiatan-kegiatan yang dilaksanakan tim pelaksana kepada mitra sebagai berikut:

Pertama, melaksanakan pelatihan bagi guru-guru SDIT DOD Medan dalam pengelolaan PJJ baik daring maupun luring. Dalam pelatihan ini guru-guru dilatih dalam pembuatan rencana pembelajaran praktis, pembuatan bahan ajar, dan metode penilaian hasil belajar. 
Dalam kegiatan ini selain memberikan pengetahuan dan teknik pengelolaan pembelajaran secara daring atau luring. Tim pelaksana pengabdian masyarakat juga memberikan pemahaman terhadap guru-guru SDIT DOD Medan tentang pentingnya keterbukaan hati dan kesadaran untuk menerima keadaan yang berubah akibat krisis pandemi Covid-19 dan mampu melakukan adaptasi terhadap situasi tersebut. Tujuannya adalah sikap terbuka dan menerima serta kemampuan beradaptasi terhadap perubahan tersebut menjadi spirit untuk melakukan hal-hal yang positif guna mendukung akivitas yang dibutuhkan dalam meningkatkan kinerja individu (Yuwono et al., 2020).

Kegiatan ini telah membuka kesadaran dan pemahaman mitra terutama guru-guru SDIT DOD Medan untuk bergerak mengembangkan kreativitas dan inovasi yang dibutuhkan guna mendukung pelaksanaan tugas sebagai guru professional.

Kemudian daripada itu, dalam pelatihan ini guruguru juga dilatih dalam menyusun rencana program pembelajaran ringkas satu halaman, pembuatan bahan ajar, metode pembelajaran di masa pandemi, dan penilaian hasil atau capaian belajar peserta didik.

Rencana program pembelajaran atau rencana pelaksanaan pembelajaran (RPP) satu halaman merupakan kebijakan Kementerian dan Kebudayaan Republik Indonesia. Menteri Pendidikan dan Kebudayaan Republik Indonesia mengeluarkan surat edaran Nomor 14 Tahun 2019 tentang Penyederhanaan Rencana Pelaksanaan Pembelajaran. Terkait dengan hal tersebut, tim pelaksana pengabdian masyarakat memberikan pendampingan bagi guru-guru SDIT DOD Medan dengan hasil guru-guru mampu menyusun RPP ringkas yang dibutuhkan dalam persiapan pelaksanaan pembelajaran.

Dalam kegiatan pelatihan tim pelaksana pengabdian menitikberatkan pada kemapuan mitra dalam menyusun bahan ajar, metode, dan penilaian hasil belajar. Guruguru SDIT DOD Medan mempersiapkan bahan ajar dalam pembelajaran di masa pandemi dengan menggunakan kertas (cetakan/print out) dan menggunakan soft copy berupa video yang disampaikan guru kepada orangtua melalui Whatsapp sebagai cara untuk menjamin keterlaksanaan pembelajaraan.

Dengan demikian dapat dijelaskan bahwa dalam mendukung pembelajaran di masa pandemi ketepatan dalam menggunakan bahan ajar, metode, dan peniliaian hasil belajar peserta didik tidak bisa ditawar-tawar. Ketiganya harus benar-benar mampu dilakukan dengan efektif dan efisien oleh guru selama pembelajaran terutama dalam situasi pandemi Covid-19. Bahan ajar dan metode yang tepat, meskipun dilaksanakan dengan PJJ akan membuat peserta didik merasa nyaman dalam menjalaninya (Mustakim, 2020). Hal ini mengisyaratkan bahwa setiap lembaga pendidikan harus mau dan mampu melakukan terobosan dalam mengelola pembelajaran di masa pandemi (Zainuddin Atsani, 2020). Hal lain yang tidak boleh diabaikan adalah penilaian hasil pembelajaran. Dalam melakukan penilaian hendaknya guru berfokus pada penguasaan sikap, keterampilan, dan pengetahuan secara utuh dari peserta didik serta memegang prinsip kesinambungan, komprehensif, objektivitas, dan mengacu pada tujuan (Suhendri, 2018).

Kedua, membantu sekolah dalam membangun LMS yang digunakan sebagai piranti pendukung pembelajaran dengan moda PJJ selama masa pandemi Covid-19. Dalam kegiatan ini, SDIT DOD Medan telah membangun LMS sederhana guna mendukung pembelajaran baik moda tatap muka maupun moda PJJ.

LMS selain memberikan kemudahan dan mendukung dalam pembelajaran jarak jauh. LMS juga mampu meningkatkan penguasaan konsep peserta didik dan pengembangan karakter peserta didik (Wibowo et al., 2014). Tentu saja hal ini menunjukkan harus adanya keseriusan guru dan tim operator dalam mengelola LMS secara tepat, terukur, dan terencana.

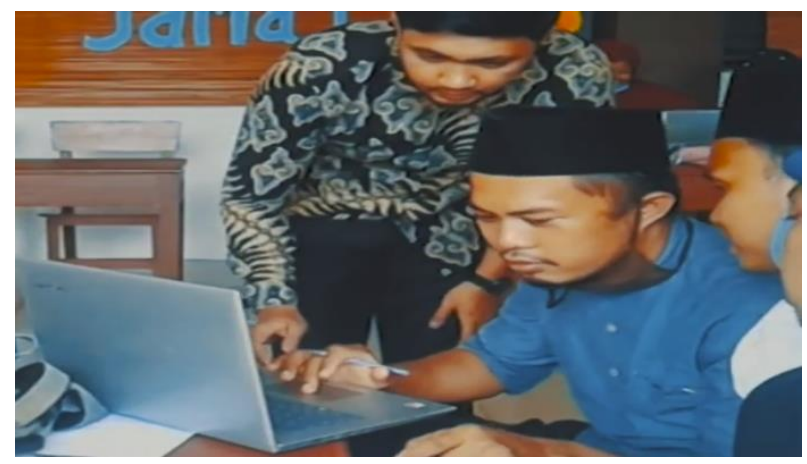

Gambar 5. Pendampingan pengelolaan LMS

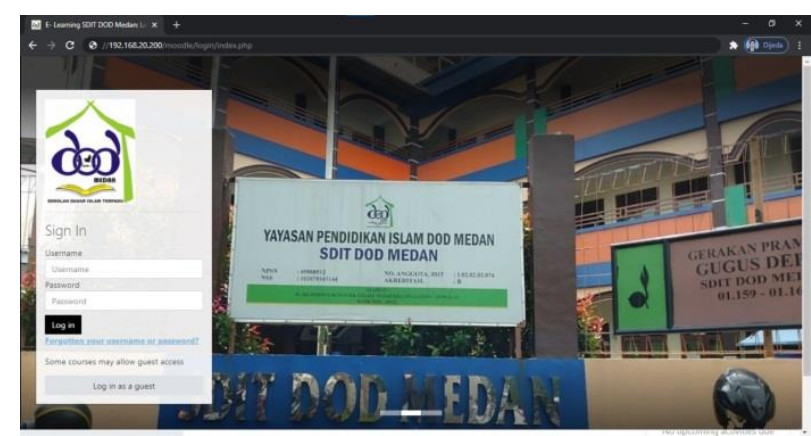


Gambar 6. Tampilan LMS SDIT DOD Medan

Ketiga, mendampingi SDIT DOD Medan dalam melaksanakan sosialisasi moda PJJ kepada orangtua dan/atau komite sekolah. Kegiatan sosialisasi moda PJJ bagi orangtua dan/atau komite sekolah menambah pengetahuan dan keterampilan teknis serta membangun kesadaran dan keterlibatan orangtua secara aktif dalam mendampingi anak-anak dalam proses pembelajaran di rumah.

Di masa pandemi Covid-19, keterlibatan orangtua dalam pembelajaran anak-anak sangatlah penting. Namun, agar pendampingan terhadap anak-anak memiliki manfaat, maka orangtua diharapkan mampu untuk: menguatkan pijakan spiritual kepada Sang Pencipta, menjunjung tinggi kasih sayang, memberikan penghargaan bagi anak, menyediakan lingkungan aman, sehat, dan bersahabat serta menjadi orangtua teladan (Suhendri, 2020). Bila ini dilakukan secara konsisten oleh orangtua dalam lingkungan keluarga, bukan saja bermanfaat bagi anak dan fase-fase serta proses pembelajaran yang dilaluinya, tapi juga akan menghasilkan ketahanan keluarga secara keseluruhan.

\section{KESIMPULAN}

Berdasarkan pelaksanaan kegiatan pengabdian masyarakat oleh tim pelaksana pengabdian Universitas Dharmawangsa, SDIT DOD Medan menunjukkan capaian bahwa: (a) Guru-guru SDIT DOD Medan memiliki kemampuan beradaptasi dengan perubahan situasi akibat pandemi Covid-19 dan memiliki kemampuan dalam mendisain baik daring maupun luring, sekolah membangun Learning Management System (LMS), dan sekolah mendapatkan dukungan orangtua di masa pandemi Covid-19.

Sebagai tindak lanjut kegiatan pengabdian masyarakat ini, diharapkan kepada pemangku kebijakan dan lembaga terkait untuk ambil bagian dalam melakukan kegiatan pendampingan dan dukungan terhadap guru-guru dalam mengelola pembelajaran sekaligus melakukan monitoring dan evaluasi terhadap proses pembelajaran selama pandemi Covid-19 dan adaptasi pembelajaran pada era kenormalan baru (new normal).

\section{UCAPAN TERIMA KASIH}

Tim pelaksana pengabdian masyarakat mengucapkan terimakasih kepada Lembaga Pengabdian Kepada Masyarakat (LPkM) Universitas Dharmawangsa yang telah memberikan dukungan pendanaan.

DAFTAR PUSTAKA

Azzahra, N. F. (2020). Ringkasan Kebijakan: Mengkaji
Hambatan Pembelajaran Jarak Jauh di Indonesia di Masa Pandemi Covid-19.

Darmayanti, Tri, Setiani, Made Yudhi, Oetojo, B. (2007). E-Learning pada Pendidikan Jarak Jauh: Konsep yang Mengubah Pembejalaran di Perguruan Tinggi Indonesia. Jurnal Pendidikan Terbuka Dan Jarak Jauh, 8(2), 99-113.

Firman \& Rahayu, S. R. (2020). Pembelajaran Online di Tengah Pandemi Covid-19. Indonesian Journal of Educational Science (IJES), 2(2), 81-89.

Herliandry, Luh Devi, Nurhasanah, Suban, Maria Enjelina, Kuswanto, H. (2020). Pembelajaran pada Masa Pandemi Covid-19. Jurnal Teknologi Pendidikan, 22(1), 65-70.

Isniatun, M. (2005). Virtual Learning dalam Pembelajaran Jarak Jauh. Majalah Ilmiah Pembelajaran, 2(1), 171-181.

Muhammad, H. (2020). Menyiapkan Pembelajaran di Masa Pandemi: Tantangan dan Peluang. Kemendikbud RI.

Mustakim. (2020). Efektivitas Pembelajaran Daring Menggunakan Media Online Selama Pandemi Covid-19 Pada Mata Pelajaran Matematika the Effectiveness of E-Learning Using Online Media During the Covid-19 Pandemic in Mathematics. Al Asma: Journal of Islamic Education, 2(1), 1-12.

Suhendri, S. (2018). Evaluasi Pendidikan Dalam Perspektif Filsafat Pendidikan Islam. Almufida: Jurnal Ilmu-Ilmu Keislaman, 3(1), 29-43. http://jurnal.dharmawangsa.ac.id/index.php/almufi da/article/view/92

Suhendri, S. (2020). Belajar dari rumah, orangtua, dan penguatan karakter. https://doi.org/10.5281/zenodo.4393509

Wibowo, A. T., Akhlis, I., \& Nugroho, S. E. (2014). Pengembangan LMS (Learning Management System) Berbasis Web untuk Mengukur Pemahaman Konsep dan Karakter Siswa. Scientific Journal of Informatics, 1(2), 127-137. https://doi.org/10.15294/sji.v1i2.4019

Yuwono, T., Wiyono, N., Asbari, M., Novitasari, D., \& Silitonga, N. (2020). Analisis Pengaruh Efektivitas Kepemimpinan Transformasional dan Kesiapan untuk Berubah terhadap Kinerja Karyawan Wanita di Masa Pandemi Covid-19. Jurnal Ilmiah Mahasiswa Ekonomi Manajemen, 5(3), 615-632. http://www.jim.unsyiah.ac.id/EKM/article/view/1 5502

Zainuddin Atsani, L. G. M. (2020). Transformasi Media Pembelajaran Pada Masa Pandemi Covid-19. AlHikmah: Jurnal Studi Islam, 1(1), 82-93. https://core.ac.uk/download/pdf/327208218.pdf 